\title{
Evaluation of Factors Affecting the Mortality and Morbidity of Patients with Acute Mesenteric Ischaemia
}

\author{
Akut Mezenterik İskemi Hastalarında Mortalite ve Morbiditeyi Etkileyen Faktörlerin \\ Değerlendirilmesi
}

\author{
(1) Ali Emre Naycı, (1) Coșkun Çakır \\ Istanbul Training and Research Hospital, Clinic of General Surgery, i̇stanbul, Turkey
}

\begin{abstract}
Introduction: Acute mesenteric ischaemia (AMI) is a disease with high mortality that is not easy to diagnose. It usually develops as a result of arterial obstructions of mesenteric vessels. In this study, we aimed to evaluate the laboratory and clinical results of patients operated for AMI.

Methods: Our study included 44 patients diagnosed with AMI between January 2014 and January 2017. From our hospital records, we included patients' demographic data, comorbid diseases, hospital admission time, blood leucocyte, platelet, amylase, lactate, $\mathrm{Ph}$, bicarbonate and lactate dehydrogenase values, preoperative abdominal computed tomography results, surgery duration, postoperative period according to the clinical course of the patients at the postoperative $48^{\text {th }}$ hour and the need for a second look and additional resection and the clinical follow-up.

Results: The patients' female/male ratio was $6 / 5$, and the mean age was $69.4 \pm 12.0$ years. Thirty-two (72.7\%) patients developed occlusion of the superior mesenteric artery due to thrombosis or embolism. Twenty-eight (63.6\%) patients underwent a second-look operation after $48 \mathrm{~h}$, and 15 of them required additional resection. The mortality rate was significantly higher in patients with hospital admission and operation time of $12 \mathrm{~h}$ or more. Lactate levels were significantly higher in the patient group with a higher mortality rate. Postoperative leucocyte value was significantly increased in the postoperative period of the first operation compared with that in the preoperative period in patients with additional resection.

Conclusion: AMI should be kept in mind in elderly patients with comorbid diseases who present to the emergency department with abdominal pain, and these patients should be approached with suspicion. High leucocyte and lactate levels may support the clinician's diagnostic opinion about AMI. In addition, the increase in leucocyte values in the postoperative period supports the ischaemia progression and the need for a second look.
\end{abstract}

Keywords: Mesenteric ischaemia, leukocyte, second look, lactate

\section{öZ}

Amaç: Akut mezenterik iskemi (AMi) kolay tanı koyulamayan ve mortalitesi yüksek bir hastalıktır. Genellikle mezenterik damarların arteriyal tıkanıklıkları sonucunda gelișir. Tanıda birçok marker kullanılmasına rağmen spesifik bir tetkik yoktur. Biz de bu çalışmamızda akut mezenterik iskemi nedeniyle opere olan hastaların laboratuvar ve klinik sonuçlarını değerlendirmeyi amaçladık.

Yöntemler: Çalışmamıza Ocak 2014-Ocak 2017 tarihleri arasında AMi tanısı alan 44 hasta dahil edilmiştir. Hastaların hastane kayıtlarından demografik verileri, komorbid hastalıkları, hastaneye bașvurma süreleri, kan lökosit, platelet, amilaz, laktat, Ph, bikarbonat ve laktat dehidrogenaz değerleri, preoperatif çekilen abdominal bilgisayarlı tomografi sonuçları, ameliyata alınma süreleri, hastaların klinik seyrine göre postoperatif 48 . saatte sekond look ve ek rezeksiyon ihtiyacı, portoperatif klinik takipleri not edilmiştir.

Bulgular: Hastaların kadın/erkek oranı 6/5, ortalama yaşı $69,4 \pm 12,0$ yıldır. Otuz iki hastada (\%72,7) süperiyor mezenterik arterda tromboz veya emboliye bağlı tıkanıklık geliștiği gözlenmiștir. Yirmi sekiz hastada $(\% 63,6) 48$ saat sonra sekond look yapılmış 15 'ine ek rezeksiyon gerekmiştir. Mortal seyreden hastalarda $\geq 12$ saat üstü ameliyata alınma süresi ile yaşayan hastalardan anlamlı olarak daha yüksekti. Mortal seyreden grupta laktat değeri yaşayan gruptan anlamlı olarak daha yüksekti. Ek rezeksiyon olan hastalarda postop lökosit değeri ilk operasyonun postop döneminde preop döneme göre anlamlı oranda artmıștır.

Sonuç: Acil servise karın ağrısı ile bașvuran, yașlı, komorbid hastalığı olan hastalarda AMi akılda tutulmalı ve bu hastalara şüpheyle yaklaşılmalıdır. Hastaların yüksek lökosit ve laktat seviyelerine sahip olması klinisyenin AMi yönündeki fikirlerine destek olabilmektedir. Ayrıca postoperatif dönemde lökosit değerlerindeki yükselme iskeminin ilerlediği ve hastanın sekond look ihtiyacı olduğunu destekler niteliktedir.

Anahtar Kelimeler: Mezenter iskemi, lokosit, second look, laktat 


\section{Introduction}

Acute mesenteric ischaemia (AMI) is a vascular emergency with high mortality and morbidity rates that can cause intestinal ischaemia and infarction. Mortality rates go up to $65 \%$ in large clinical series $(1,2)$. An important cause of high mortality rates is delayed diagnosis and treatment (2).

The major aetiologies of mesenteric ischaemia are as follows: 50\% mesenteric arterial embolism, 15-25\% mesenteric arterial thrombosis, $5 \%$ mesenteric venous thrombosis and 20\%-30\% non-occlusive mesenteric ischaemia causing intestinal hypoperfusion $(3,4)$.

Open surgery is the most commonly used treatment method for mesenteric ischaemia. In addition, endovascular treatment methods such as percutaneous transluminal angioplasty and stent placement are among the treatment options that can be used (5). There are reports that endovascular treatment provides faster perfusion compared with open surgical revascularisation and reduces mortality and morbidity rates $(6,7)$.

Patients with mesenteric ischaemia have severe abdominal pain incompatible with a physical examination. Since ischaemia progresses transmurally in many patients, the diagnosis can usually be made after patients develop peritonitis and sepsis. Several imaging methods are used for diagnosis. Abdominal X-ray, abdominal ultrasonography and non-contrast computed tomography (CT) are negligible for diagnosis. It has been reported that intravenous contrast-enhanced $\mathrm{CT}$ is more appropriate to use in the first-line diagnosis because of its reported high sensitivity and specificity $(8,9)$. Although some guidelines suggested that angiography is the gold standard in the diagnosis of mesenteric ischaemia, they reported that CT angiography should be used as the first choice of diagnosis because angiography is an invasive procedure, difficult to access and has a long procedure time $(8,10,11)$.

Unfortunately, a biochemical parameter that can be used specifically for the diagnosis of mesenteric ischaemia has not been reported. According to the World Society of Emergency Surgery guideline, an increase in L-lactate and D-dimer levels can be used to diagnose mesenteric ischaemia. In addition, intestinal fatty acid-binding protein, serum alpha-glutathione S-transferase and nesfatin-1 can be used as auxiliary diagnostic parameters for mesenteric ischaemia, although there is no definitive marker $(8,12)$.

In this study, we aimed to discuss the laboratory and clinical results of patients with AMI.

\section{Methods}

This study is a retrospective analysis of AMI patients and approved by the Local Ethics Committee İstanbul Training and Research Hospital (decision no: 2038, date: 25.10.2019). Written informed consent was obtained from all cases. Between January 2014 and January 2017, more than 2,000 acute abdomen patients were admitted to the emergency service of our hospital. Of these patients, 44 had AMI diagnosis and included in this study. The patients who could not be followed up in our hospital after the surgery were excluded from the study.

Parameters included in this study were from the hospital records. Demographic data, comorbid diseases, hospital admission time, blood leucocyte, platelet, amylase, lactate, $\mathrm{Ph}$, bicarbonate and lactate dehydrogenase values, preoperative abdominal CT results, surgery duration, the need for secondary resection and additional resection at postoperative $48^{\text {th }}$ hour and postoperative clinical follow-up were noted.

Comparisons were made based on patient data, which were divided into subgroups based on whether patients have died after surgery or require a second look.

\section{Statistical Analysis}

SPSS 22.0 programme was used to analyse the variables evaluated in the study. The Kolmogorov-Smirnov test measured the distribution of the data. Independent t-test and Mann-Whitney $U$ test analysed quantitative independent data and Wilcoxon test for the dependent quantitative data. The chi-square test analysed qualitative independent data, and Fisher's exact test was used when chi-square test conditions were not met.

\section{Results}

A total of 44 patients were included in the study, with a female/male ratio of $6 / 5$ and mean age of $69.4 \pm 12.0$ years. Only four (9.1\%) patients had no comorbid diseases. Considering the aetiology of AMI, 32 (72.7\%) patients developed thrombosis occlusion or embolism in the superior mesenteric artery. In 28 (63.6\%) patients included in the study, a secondlook operation was performed after $48 \mathrm{~h}$. Of these patients, 15 required additional resection as a result of intestinal ischaemia. CT results, surgery duration and blood test results are presented in Table 1.

The data collected in the study were re-evaluated according to the effects on mortality. Patients who developed mortality within 28 days were included in the mortality group. There was no significant difference between the two groups in terms of age, sex distribution, intestinal wall gas rate, $\mathrm{CT}$ anomaly rate, comorbid disease rate, second-look rate and additional resection rate $(p>0.05)$. In the mortality group, time lag or $\mathrm{a}>12 \mathrm{~h}$ gap from the admission/presentation to the operation was significantly higher than in the living group $(p=0.013)$. There was no significant difference between the two groups in the blood levels of the patients except lactate levels, which were significantly higher in the mortality group $(\mathrm{p}=0.003$; Table 2$)$.

When the patients undergoing a second-look operation were divided into two groups with and without additional resection, the preoperative and postoperative leucocyte counts were compared between the first operation and second-look surgery. The leucocyte values in the group without additional resection were $22.5 \pm 7.1 \times 10^{3}$ and $20.5 \pm 8.5 \times 10^{3}$ in the postoperative and preoperative periods, respectively, and no significant difference was observed between them $(p=0.552)$. In the group with additional resection, the postoperative leucocyte value was $28.0 \pm 11.4 \times 10^{3}$ and preoperative $18.9 \pm 9.8 \times 10^{3}$, and the leucocyte value increased significantly in the postoperative period $(p=0.001)$. Again, there was no significant difference in the leucocyte values in the patients who required and did not require additional resection during the second look ( $p=0.170)$. 
Table 1. Distribution of demographic and clinical information of all patients

\begin{tabular}{|c|c|c|c|}
\hline & Mean \pm SD & n (\%) \\
\hline \multicolumn{2}{|l|}{ Age (years) } & $69.4 \pm 12.0$ & - \\
\hline \multirow{2}{*}{ Gender } & Women & - & $24(54.5)$ \\
\hline & Men & - & $20(45.5)$ \\
\hline \multirow{2}{*}{ Intestinal wall gas in CT } & No & - & $25(56.8)$ \\
\hline & Yes & - & $19(43.2)$ \\
\hline \multirow{2}{*}{ CT abnormality } & Normal & - & $4(9.1)$ \\
\hline & Abnormal & - & $40(90.9)$ \\
\hline \multirow{2}{*}{$\begin{array}{l}\text { Time between the admission/ } \\
\text { presentation and the operation (h) }\end{array}$} & $<12$ & - & $23(52.3)$ \\
\hline & $\geq 12$ & - & $21(47.7)$ \\
\hline \multirow{2}{*}{ Comorbid diseases } & No & - & $4(9.1)$ \\
\hline & Yes & - & $40(90.9)$ \\
\hline \multirow{2}{*}{ Second look } & No & - & $16(36.4)$ \\
\hline & Yes & - & $28(63.6)$ \\
\hline \multirow{2}{*}{ Additional resection } & No & - & $29(65.9)$ \\
\hline & Yes & - & $15(34.1)$ \\
\hline \multicolumn{2}{|l|}{ Preoperative leucocyte value } & $19.9 \pm 8.9$ & - \\
\hline \multicolumn{2}{|l|}{ Postoperative leucocyte value } & $21.4 \pm 10.7$ & - \\
\hline \multicolumn{2}{|l|}{ Platelet value } & $245.4 \pm 27.4$ & - \\
\hline \multicolumn{2}{|l|}{ Arterial blood Ph } & $7.3 \pm 0.1$ & - \\
\hline \multicolumn{2}{|l|}{ Amylase } & $195.0 \pm 140.4$ & - \\
\hline \multicolumn{2}{|l|}{ Lactate } & $4.3 \pm 2.3$ & - \\
\hline \multicolumn{2}{|l|}{ Bicarbonate } & $20.2 \pm 2.8$ & - \\
\hline \multicolumn{2}{|l|}{ Lactate dehydrogenase } & $384.0 \pm 183.1$ & - \\
\hline \multicolumn{4}{|c|}{ SD: standard deviation, CT: computed tomography } \\
\hline
\end{tabular}

\section{Discussion}

The aetiological cause in $70 \%-80 \%$ of cases of $\mathrm{AMI}$ is obstruction of the mesenteric artery due to an embolism or thrombus and consequent intestinal ischaemia. Compared with other causes of AMI, embolic occlusion results in early ischaemia and transmural necrosis due to the absence of well-developed collateral circulation (13). The diagnosis of AMI is based on clinical suspicion and symptoms, and severe abdominal pain is disproportionate to physical examination findings. Intestinal ischaemia progresses transmurally, and in most cases, peritonitis and sepsis have occurred before diagnosis (14). In our study, postoperative mortality was lower in patients who were diagnosed and operated within $12 \mathrm{~h}$ of admission to the emergency department, indicating the effect of early diagnosis on mortality.

AMI is generally seen in the elderly population, and some studies reported that increasing age is a negative prognostic criterion for mesenteric ischaemia. Conversely, there are also reports that age does not correlate with AMI prognosis (14). In our study, no significant difference was found between the patients who have died and those who were alive in the postoperative period.

Arterial occlusions due to arterial embolism and thrombosis usually occur in superior mesenteric artery (SMA). Venous thrombosis develops as a result of obstructions in the superior and inferior mesenteric veins, splenic vein and portal veins (15). In our study, it was observed that the majority of patients developed AMI as a result of embolism or thrombosis in SMA. Intestines can tolerate a 75\% reduction in mesenteric blood flow by up to $12 \mathrm{~h}$ by vasodilatation of collaterals and increase of oxygenation (16). However, prolonged ischaemia causes vasoconstriction in the occluded vessels and increases the pressure in collateral flow and decreases the flow $(3,17)$.

Although CT is useful in ruling out other causes of acute abdominal pain, focal or segmental bowel wall thickening, gas presence in the portal vein with intestinal pneumatosis, bowel dilatation, mesenteric rotation, portomesenteric thrombosis and malignancy or solid organ blood supply disorders are also compatible with the findings $(18,19,20)$. Although tomography is sensitive to intestinal wall changes in AMI, it should be kept in mind that it is not specific $(18,19)$. The presence of pneumatosis intestinalis in tomography does not necessarily indicate the occurrence of transmural infarction, but pneumatosis and portomesenteric venous gas are highly probable in the case of transmural infarction (21). Mesenteric artery obstructions are observed as filling defects in arterial vasculature by time-adjusted intravenous contrast injections. This is specific for the diagnosis of thromboembolic occlusion; however, the absence of a filling defect is not sufficient to exclude AMI $(18,19)$. In our study, intestinal pneumatosis was observed in $43.2 \%$ of patients, and secondary findings of AMI, such as focal or segmental bowel wall thickening, intestinal dilatation and mesenteric artery filling defects, were observed in $90.9 \%$ of patients.

Although the American College of Gastroenterology guidelines reported that angiography is the gold standard in the diagnosis of mesenteric ischaemia, CT angiography, which is a non-invasive technique with 96\% sensitivity and 94\% specificity, is reported to be more appropriate because angiography is an invasive procedure, difficult to access and takes longer time $(8,10,11)$. In our study, angiography was not performed in any patient because it was an invasive procedure and had limited accessibility; instead, diagnoses were performed following the CT angiography protocol.

Many laboratory tests have been examined in the diagnosis of mesenteric ischaemia or infarction (22). In a review, the sensitivity and specificity of L-lactate levels were $86 \%$ and $44 \%$, respectively, for AMI (23). It is reported that the specificity of high serum lactate level increases significantly when conditions such as shock, diabetic ketoacidosis and renal and liver failure are excluded (24). Elevated serum amylase levels were observed in approximately half of the patients with intestinal ischaemia $(25,26)$, whereas phosphate levels were elevated in $80 \%$ of patients $(27)$. Increases in blood urea, creatinine and amylase levels, leucocyte count, and acidosis have been accepted as indicators of mortality in different studies $(28,29)$. Although not statistically significant, some studies have reported that the development of leucopenia increases mortality and that this is due to the decrease in the protective effect of the immune system (30). In our study, only lactate levels were found to be significantly elevated in postoperative patients who have died. We did not find any studies investigating the blood leucocyte values between the resection and non-resection groups in patients who underwent a second look for 
Table 2. Comparison of demographic and clinical data of alive and exitus patients in the postoperative period

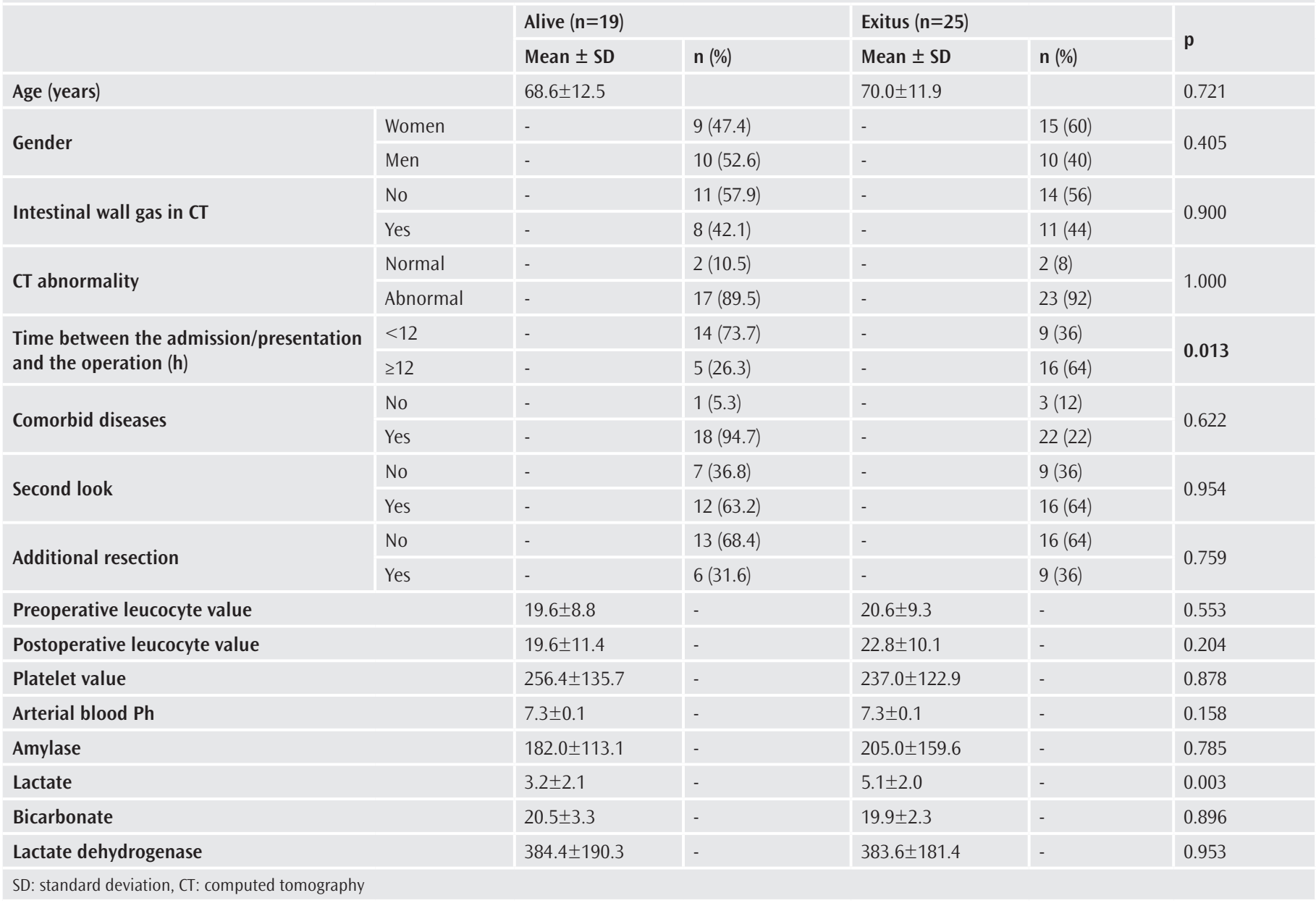

AMI. In our study, there was no significant difference in blood leucocyte values between the resection and non-resection groups during the second look, but there was a significant difference between the blood tests taken at the time of the first admission to the hospital and the leucocyte values taken before the second look.

\section{Conclusion}

AMI should be kept in mind in elderly patients with comorbid diseases who present to the emergency department with abdominal pain, and these patients should be approached with suspicion. The lack of high sensitivity and specificity tests in the diagnosis of AMI causes delays in the diagnosis, and the later operation of the patients is one of the important reasons that increase mortality. High leucocyte and lactate levels may support the clinician's diagnostic opinion about AMI. In addition, the increase in leucocyte values in the postoperative period supports the ischaemia progression and the need for a second look.

\section{Ethics}

Ethics Committee Approval: This study is a retrospective analysis of AMI patients and approved by the Ethics Committee of İstanbul Training and Research Hospital (decision no: 2038, date: 25.10.2019).
Informed Consent: Written informed consent was obtained from all cases.

Peer-review: Externally peer-reviewed.

Authorship Contributions: Surgical and Medical Practices - A.E.N., C.C..; Concept- A.E.N., C.C..; Design - A.E.N.; Data Collection or Processing A.E.N., C.C..; Analysis or Interpretation - A.E.N., C.Ç.; Literature Search - A.E.N., C.Ç.; Writing - A.E.N., C.Ç.

Conflict of Interest: No conflict of interest was declared by the authors.

Financial Disclosure: The authors declared that this study received no financial support.

\section{References}

1. Stoney RJ, Cunningham CG. Acute mesenteric ischemia. Surgery 1993; 114: 489-90.

2. Oldenburg WA, Lau LL, Rodenberg TJ, Edmonds HJ, Burger CD. Acute mesenteric ischemia: a clinical review. Arch Intern Med 2004; 164: 1054-62.

3. Reinus JF, Brandt LJ, Boley SJ. Ischemic diseases of the bowel. Gastroenterol Clin North Am 1990; 19: 319

4. Zhao Y, Yin H, Yao C, Deng J, Wang M, Li Z, et al. Management of Acute Mesenteric Ischemia: A Critical Review and Treatment Algorithm. Vasc Endovascular Surg 2016; 50: 183-92. 
5. Resch T, Lindh M, Dias N, Sonesson B, Uher P, Malina M, et al. Endovascular recanalisation in occlusive mesenteric ischemia--feasibility and early results. Eur J Vasc Endovasc Surg 2005; 29: 199-203.

6. Foley MI, Moneta GL, Abou-Zamzam AM Jr, Edwards JM, Taylor LM Jr, Yeager $\mathrm{RA}$, et al. Revascularization of the superior mesenteric artery alone for treatment of intestinal ischemia. J Vasc Surg 2000; 32: 37-47.

7. Schoots IG, Levi MM, Reekers JA, Lameris JS, van Gulik TM. Thrombolytic therapy for acute superior mesenteric artery occlusion. J Vasc Interv Radiol 2005; 16: 317-29.

8. Tatar C, Ahlatci FA, Idiz UO, Nayci AE, Incir S, Agcaoglu O, et al. May Nesfatin-1 be a Biomarker in Acute Mesenteric Ischemia? J Coll Physicians Surg Pak 2019; 29: 928-31.

9. Copin P, Zins M, Nuzzo A, Purcell Y, Beranger-Gibert S, Maggiori L, et al. Acute mesenteric ischemia: A critical role for the radiologist. Diagn Interv Imaging 2018; 99: 123-34.

10. Kirkpatrick ID, Kroeker MA, Greenberg HM. Biphasic CT with mesenteric CT angiography in the evaluation of acute mesenteric ischemia: Initial experience. Radiology 2003; 229: 91-8.

11. Wyers MC. Acute mesenteric ischemia: Diagnostic approach and surgical treatment. Semin Vasc Surg 2010; 23: 9-20.

12. Bala M, Kashuk J, Moore EE, Kluger Y, Biffl W, Gomes CA, et al. Acute mesenteric ischemia: Guidelines of the World Society of Emergency Surgery. World J Emerg Surg 2017; 12: 38.

13. Hokama A, Kishimoto K, Ihama Y, Kobashigawa C, Nakamoto M, Hirata T, et al. Endoscopic and radiographic features of gastrointestinal involvement in vasculitis. World J Gastrointest Endosc 2012; 4: 50-6.

14. Yıldııım D, Hut A, Tatar C, Dönmez T, Akıncı M, Toptaş M. Prognostic factors in patients with acute mesenteric ischemia. Turk J Surg 2017; 33: 104-9.

15. Bulkley GB, Kvietys PR, Parks DA, Perry MA, Granger DN. Relationship of blood flow and oxygen consumption to ischemic injury in the canine small intestine. Gastroenterology 1985; 89: 852.

16. Boley SJ, Frieber W, Winslow PR. Circulatory responses to acute reduction of superior mesenteric arterial flow. Physiologist 1969; 12: 180.

17. McKinsey JF, Gewertz BL. Acute mesenteric ischemia. Surg Clin North Am 1997; 77: 307.
18. Ofer A, Abadi S, Nitecki S, Karram T, Kogan I, Leiderman M, et al. Multidetector $\mathrm{CT}$ angiography in the evaluation of acute mesenteric ischemia. Eur Radiol 2009; 19: 24.

19. Aschoff AJ, Stuber G, Becker BW, Hoffmann MHK, Schmitz BL, Schelzig H, et al. Evaluation of acute mesenteric ischemia: accuracy of biphasic mesenteric multi-detector CT angiography. Abdom Imaging 2009; 34: 345.

20. Işık A, Eken H, Demiryılmaz I, Yılmaz I, Fırat D, Çimen O, et al. Rectum, Lymphoma, Adenocancer. Turk J Colorectal Dis 2015; 25: 106-8.

21. Kernagis LY, Levine MS, Jacobs JE. Pneumatosis intestinalis in patients with ischemia: correlation of CT findings with viability of the bowel. AJR Am J Roentgenol 2003; 180: 733.

22. Glenister KM, Corke CF. Infarcted intestine: a diagnostic void. ANZ J Surg 2004; 74: 260 .

23. Cudnik MT, Darbha S, Jones J, Macedo J, Stockton SW, Hiestand BC. The diagnosis of acute mesenteric ischemia: A systematic review and metaanalysis. Acad Emerg Med 2013; 20: 1087.

24. Lange $H$, Jäckel R. Usefulness of plasma lactate concentration in the diagnosis of acute abdominal disease. Eur J Surg 1994; 160: 381.

25. Wilson C, Imrie CW. Amylase and gut infarction. Br J Surg 1986; 73: 219.

26. Gearhart SL, Delaney CP, Senagore AJ, Banbury MK, Remzi FH, Kiran RP, et al. Prospective assessment of the predictive value of alpha-glutathione S-transferase for intestinal ischemia. Am Surg 2003; 69: 324.

27. Jamieson WG, Marchuk S, Rowsom J, Durand D. The early diagnosis of massive acute intestinal ischaemia. Br J Surg 1982; 69 (Suppl): S52.

28. Aliosmanoglu I, Gul M, Kapan M, Arikanoglu Z, Taskesen F, Basol O, et al. Risk Factors Effecting Mortality in Acute Mesenteric Ischemia and Mortality Rates: A Single Center Experience. Int Surg 2013; 98: 76-81.

29. Merida MAA, Gomez JM, Miller MH, Castellano CR, Romero JMH. Identification of risk factors for perioperative mortality in acute mesenteric ischemia. World J Surg 2006; 30: 1579-85.

30. Mamode N, Pickford I, Lieberman P. Failure to improve outcome in acute mesenteric ischemia: seven-year review. Eur J Surg 1999; 165: 203-8. 